\title{
The Innovative Nature of Consumer Law
}

\author{
Ewoud Hondius
}

Received: 15 September 2011 / Accepted: 10 January 2012 /

Published online: 16 February 2012

C The Author(s) 2012. This article is published with open access at Springerlink.com

Keywords Consumer·President Kennedy $\cdot$ Innovation · Europeanisation

\section{Birth of a New Discipline}

On 15 March 2012, Consumer Law will celebrate its $50^{\text {th }}$ birthday. On that day in 1962 , President John F. Kennedy famously read his Special Message on Protecting the Consumer Interest to the American Congress. The Message, which begins with the oft-quoted words "Consumers, by definition, include us all," enumerates four basic consumer rights:

“(1) The right to safety - to be protected against the marketing of goods which are hazardous to health or life.

(2) The right to be informed - to be protected against fraudulent, deceitful, or grossly misleading information, advertising, labelling, or other practices, and to be given the facts he needs to make an informed choice.

(3) The right to choose - to be assured, wherever possible, access to a variety of products and services at competitive prices; and in those industries in which competition is not workable and Government regulation is substituted, an assurance of satisfactory quality and service at fair prices.

Keynote lecture, ius commune conference, Leuven, 25 November 2010. The author is grateful to JCP's anonymous external examiner for his or her useful comments.

E. Hondius $(\bowtie)$

Ius Commune Research School, University of Utrecht, Utrecht, The Netherlands e-mail: e.h.hondius@uu.nl 
(4) The right to be heard - to be assured that consumer interests will receive full and sympathetic consideration in the formulation of Government policy, and fair and expeditious treatment in its administrative tribunals."

These rights should not be misunderstood as to have the nature of fundamental rights, to be enshrined in a Constitution. ${ }^{2}$ They rather were suggested as political rights, together presenting a programme for the legislature. ${ }^{3}$ That at least is what the two main international organizations in Europe had in mind when in the next decade they took over Kennedy's idea. The Council of Europe was the first to do so, ${ }^{4}$ but for our purposes, much more importantly, it was the European Union which in 1975 established the First Consumer Protection Programme. Under the Programme, five fundamental rights of consumers were enumerated:

1. The right to protection of health and safety

2. the right to protection of economic interests

3. the right to redress

4. the right to information and education

5. the right of representation (the right to be heard)

The Programme has been updated at various occasions; at present, the EU Consumer Policy strategy 2014-2020 is in force. ${ }^{5}$ The First Consumer Protection Programme has been implemented in a large number of directives. ${ }^{6}$ So many have been issued, that codification or compilation has even been considered. ${ }^{7}$

Pinpointing the birth of Consumer Law on precisely 15 March 1962 will not be uncontested. Elements of what now is considered Consumer Law have existed for millennia. The Germans will observe that their 1894 Abzahlungsgesetz (Augenhofer 2010) paved the way; Iraq may boast of its Codex Hammurabi which four millenia ago already contained some stiff penalties for consumer fraud. Other legal systems will have other memorable starting points. ${ }^{8}$ But it is also true that only since the 1960 s have these elements been

\footnotetext{
${ }^{1}$ To be found in www.presidency.ucsb.edu/.

${ }^{2}$ Kennedy probably was eager to associate himself, as all Democratic presidents of the USA have sought, with the Four freedoms speech of President Franklin Roosevelt, delivered on January 6, 1941. In this annual message to the American Congress, Roosevelt articulated his vision for a more perfect world, where there would be freedom of speech, freedom of worship, freedom from want, and freedom from fear (www.carnegiecouncil.org).

${ }^{3}$ Kennedy was still somewhat hesitant about legislation: "To promote the fuller realization of these consumer rights, it is necessary that existing Government programs be strengthened, that Government organization be improved, and, in certain areas, that new legislation be enacted."

${ }^{4}$ A decade later, for economic reasons the Council of Europe abandoned most of its work in consumer matters.

${ }^{5}$ COM(2011) 707 final.

${ }^{6}$ See the overview in Schulte-Nölke et al. (2008)

${ }^{7}$ The original plan to integrate eight directives was abandoned in 2008, when the proposal for a Consumer Rights directive only included four such directives: those on consumer sales, distance sales, doorstep selling, and unfair contract terms - see Twigg-Flesner (2010). In December 2010, in order to save the proposed maximum harmonization, a further two directives were dropped from the project: consumer sales and unfair contract terms. The resulting Consumer Rights Directive (2011) therefore only encompasses a meagre two directives: on distance sales and doorstep selling - a far cry from the original idea.

${ }^{8}$ In France, Louis XI published an edict in 1481 which ran as follows: "Tout homme qui aura vendu du beurre contenant navets, pierres ou autres choses sera bien curieusement attaché à notre pilori, puis ledit beurre sera rudement pose sur sa tête et laissé tant que le soleil ne l'aura pas entièrement fondu. Pourrons les chiens le venir lécher et le menu peuple l'outrager par telles épithètes diffamatoires qu'il lui plaira sans offenser Dieu ni le roi. A tout homme qui aura vendu du lait mouillé sera mis un entonnoir dedans la gorge et ledit lait mouillé sera entonné jusqu'à temps qu'un médecin ou un barbier dise qu'il n'en peut, sans danger, avaler davantage."
} 
combined in a single notion. ${ }^{9}$ However, solving the birth puzzle is not something I will deal with in this paper. Rather I want to find out whether or not Consumer Law has or has had an innovative character. ${ }^{10}$ What should we understand under innovative? In a commentary of the Draft Common Frame of Reference (DCFR), edited by European University Institute's Hans Micklitz and Fabrizio Cafaggi, one of the chapters by Florian Möslein analyses legal innovation in the DCFR (Möslein 2010). Möslein found relatively little research on legal innovation. He quotes Duffy as arguing that "legal change is treated as if it is something that just happens - that follows inexorably from the emergence of social needs and changed social conditions" (Duffy 2007). Actually, there is quite a lot of research on innovation in general. ${ }^{11}$ There also is research on legal change which is not mentioned by the author. In recent years, the Cambridge European Legal Development series has attempted "to cast some light on the factors which have influenced the way in which the law has changed over [time]" and which has resulted in the publication of six volumes (Ernst 2010; Gordley 2010; Hondius 2010; Jansen 2010; Martín-Casals 2010; Whittaker 2010). Another such project has been the Shifts in liability series, which aimed at "researching the shifts in paradigm with regard to compensation for damage across the borderline between civil law (notably the law of torts, insurance law and the law of labour contracts) and public funding."12 But it is true that the keyword "innovation" has not been used in these two series of studies. ${ }^{13}$ Innovation is also one of the themes of the annual conferences of the Hague Institute for the Internationalisation of Law, which in 2011 was devoted to the law of the future. ${ }^{14}$

\section{What is Innovative in Consumer Law?}

What then may be said to be innovative in Consumer Law? Of the various candidates, four such developments may be singled out. Consumer Law research has paved the way for a European approach in national law. Consumer Law has demonstrated that pacta sunt servanda is not the only paradigm of private law. On the other hand, it may have contributed to the erosion of the nulla poena principle in public law. Consumer Law has been a key element in the movement towards a better understanding of law and other disciplines. New tools have been introduced, such as the cooling-off period, the information requirement and collective action. Each of the developments will be highlighted below.

There is one kind of change which is outside the scope of this paper. That is the change which may have come about by the activities of Consumer organizations. Participating in a number of world conferences of such organizations in the second half of last century, it has often struck me that many organizations from developing nations had a far broader agenda than those from Western Europe, Australasia, and North America. The explanation for this

\footnotetext{
9 The "consumer" notion itself is much older, but until then had mainly been used in political economy.

${ }^{10}$ And not the reverse: whether consumer law has an effect on innovation-as to this kind of research see for instance James Waters, The effect of the Sarbanes-Oxley Act on innovation, University of Westminster School of Law Research Paper No. 11-04

${ }^{11}$ See for instance Arentsen et al. (2010).

12 van Boom and Faure (2007). The two other volumes in this series are Klosse and Hartlief (2007) and Faure and Verhey (2007).

${ }^{13}$ After this paper was finished, the author became aware of a Swiss Festschrift with the title "innovative:" (Lorandi and Staehelin 2011).

${ }^{14}$ See Muller et al. (2011) and www.lawofthefuture.org.
} 
was that in developing nations consumer protection was considered as innocuous, which led proponents of political change to choose the less dangerous way of consumer protection for their activities.

\section{Engine for Europeanization}

First, the most obvious contribution of Consumer Law to the development of law in Europe has been to serve as an engine for the Europeanization of the law. This has gone so far, that some authors fear that the consumer has turned into no more than an instrument to make the internal market work. ${ }^{15}$ And more is to come, witness the recent Consumer Rights directive mentioned above.

Europeanization seems only the beginning. At a defence of a (his) $\mathrm{PhD}$ thesis, the late Gerrit Betlem once observed: "I am sorry that for practical reasons my comparative law has been restricted to Europe." It may be predicted that in the coming decade there will be a shift from European towards global law. ${ }^{16}$ And indeed, globalization may be expected to overtake Europeanization this decade.

\section{Protection of Weaker Party Turns into Paradigm}

Second, consumer protection is one of various examples of protection of the weaker party in Contract Law. Other examples include the employee, the hire-purchasor, the patient, the tenant, and the user of public service. This has meant that the paradigm of freedom of contract has not been replaced, but is now accompanied by the parallel paradigm of protection of the weaker party. ${ }^{17}$

This view is not wholly uncontested. In a recent German Habilitationsschrift it was not even considered worthy of serious discussion (Reymann 2009). This is strange, because not only in the Netherlands_-by Anne Keirse (2009) — but also in the German language such ideas have been expressed, notably by Brigitta Lurger. ${ }^{18}$ The practical consequences are of importance.

On the European level, the discussion currently focusses on the role of good faith. The DCFR's liberal stance in this regard is bitterly opposed by those who fear legal security may be threathened (Eidenmüller et al. 2008).

\section{The Decreasing Importance of Nulla Poena}

Consumer protection is often still conceived of as a private law instrument. This assumption no longer is the truth, the whole truth and nothing but the truth. Increasingly, administrative law is being used for such protection purposes. An example is the dual nature of Dutch consumer protection, which on the one hand is still enforced through private law, but on the other hand is increasingly enforced through administrative law (van Nimwegen 2010; van Kampen 2011).

\footnotetext{
${ }^{15}$ Various authors in: Brownsword et al. (2011).

${ }^{16}$ See Faure and van der Walt (2010).

${ }^{17}$ Which, some may argue, does reinforce freedom of contract, because without such protection the weaker party actually has no freedom, but instead is forced to contract on whatever terms the stronger party is inclined to offer: cf. Henri Lacordaire's "entre le fort et le faible, c'est la liberté qui opprime et la loi qui libère."

${ }^{18}$ See Lurger (2010).
} 
Fines which are issued by the new Consumer Authority often are contested in court on the basis that the basic norms which allegedly are encroached are too vague; condemnation would therefore be in violation of the maxim that no deed is punishable without previous law. ${ }^{19}$ It is often overlooked that administrative law has long found ways to cope with open norms. ${ }^{20}$

\section{Meeting Place with Other Disciplines}

Fourth, consumer protection has always been a fertile meeting place for law and other disciplines, witness the Journal of Consumer Policy. With other legal subdisciplines the relation has sometimes been somewhat uneasy. Environmental law shares many techniques with consumer protection, but its adepts loathe consumerism. Law and economics abhors the paternalistic mood of consumer protection. The same is sometimes ${ }^{21}$ true for competition law.

\section{New Techniques: Cooling-Off Period}

The cooling-off period has not been invented by Consumer Law, but it is fair to say that Consumer Law has greatly contributed to its development. Nowhere in Europe has the $\mathrm{PhD}$ thesis reached the pinnacles it has climbed to in Belgium; one of these great ouvrages is the doctoral thesis of Evelyne Terryn on the right of withdrawal. An English language summary can be found in the Casebook on Consumer Law (Rott and Terryn 2010).

\section{New Techniques: Information Requirement}

As we have already seen, the European Commission's original 2008 Proposal for a Directive on consumer rights was criticized mainly because of the total harmonization which it sought - and as of 2011 in its final version still seeks - to attain. ${ }^{22}$ In order not to risk the proposal's rejection, Commissioner Viviane Reding has retained total harmonization, but dropped the two most contentious directives. Untouched by the amendments are the Directive's provisions on consumer information. ${ }^{23}$

Although this may sound novel to some, the imposition of information requirements is not a wholly XXIst century invention, witness earlier publications such as the one by Vranken (1989). As of late it has come under some renewed pressure from circles of law and behavioural economics (Luth 2010).

\section{New Techniques: Small Claims and Collective Action}

Consumer Law vies with environmental law for the innovative character of its procedural devices. Even more so than environmental law, consumer protection may be said not to be worth anything

\footnotetext{
${ }^{19}$ See Evelyne Terryn, Nulla poena sine lege, sine poena nulla lex, inaugural lecture University of Amsterdam, to be published in Tijdschrift voor Privaatrecht.

20 See Klap (1994).

${ }^{21}$ Not always: see for instance Keirsbilck (2011).

22 See Gsell and Herresthal (2009) and Stürner (2010).

23 See Loos (2011).
} 
if enforcement is not guaranteed. And more than the environment, consumer protection has a substantive interest in a simple, speedy, and inexpensive way of conlict handling. ${ }^{24}$

Small claims procedures are an invention of the common law. The most innovative idea here is that even when he loses the procedure, the consumer does not have to pay the (litigation) costs of the other party.

In the Netherlands, the geschillencommissies do the same. Consumers who win their case are sometimes disagreeably surprised when their claims of costs - such as travelling, telephone calls, photocopies, legal advice, distress - are denied (with the exception of the fee they had to pay to have their claim heard). On the other hand, it is my personal experience that when it is explained to consumers that the other side of the coin would be that in case they would lose the case, they would have to bear the costs of the business firm, they usually appreciate the system that in principle no costs are awarded. The possibility of having to pay for the costs of the other party is indeed one of the main elements which thwart an efficient enforcement of consumer claims.

One of the problems of enforcement of consumer claims is, as we have seen their limited value. Instead of focussing on individual litigation, another option may be that of collective action. The possibilities for groups of consumers and for consumer organizations to ask for an injunction. Yet another option which has gained some success in the Netherlands is that of the 2005 Collective settlement of mass damages act. The operation of this option has been described in detail by Hodges (2008) and by Van Boom. ${ }^{25}$

\section{Competition as a Basis for Innovation}

When analysing the place of consumer law in legal research, there is also another meaning which the question may pose: in which domain should consumer law find a place? Should it be in private or in public law, in civil or in commercial law, in substantive or in procedural law? And should the solutions be the same at a national and an international level? As for the first question, there is no doubt that consumer protection consists of both public and private law. In public law, issues such as consumer safety are addressed. Private law rather focuses on the relation between individual consumers and enterprises. The distinction between civil and commercial law-beginning with Italy's 1942 Codice civile-has now been abolished in many EU member states. Where it still exists, both lay claims to consumer protection.

The last-mentioned difference has its equivalent in a fierce battle. Should consumer protection be enshrined in a Civil Code (Germany, the Netherlands), a Trade practices act (Belgium) or a Consumer Code (France, Italy, Luxemburg). Earlier, I have opted for the former, basically for two reasons. In the first place, if a jurisdiction does have a Civil Code, it would be rather strange if the Code were not to deal with the most common of all specific contracts and the most common of all problems with contracts: that of the unfairness of contract terms. Secondly, precisely dealing with the protection of consumers, together with that of employees, hire-purchasers, patients and tenants, turns the Civil Code into an instrument which not only enshrines freedom of contracts as its paradigm, but the protection of the weak party as well.

\footnotetext{
${ }^{24}$ In environmental cases, the very fact that a court is willing to hear a case- - with all its publicity-is valued by environmental protection groups.

${ }^{25}$ See van Boom (2009).
} 


\section{Innovation in Other (Sub)Disciplines}

Consumer law is not the only functional subdiscipline of law. Construction law, environmental law health law, and many other such subdisciplines vie for their independence. Innovation often serves as an argument in their quest for national acceptance. ${ }^{26}$

The development of functional subdisciplines such as Consumer Law is not without its drawbacks. Whenever new rules are formulated, demarcation problems arise. Who is the consumer: what about the trader who enters into an agreement as to goods or services in which he is not an expert. And how about the average and the informed consumer? In at least two instances, consumer law has come up with innovative demarcation lines. The most radical one of these is by simply eradicating the distinction and accepting the consumer protection merely as a catalyst. Inertia selling and the package travel contract are two examples. Neither requires the protected party - the inert buyer and the travelor - to be a consumer: professional buyers and travelors are protected as well. Another techniqe has been used in the protection against unfair contract terms. Here, the general clause aims at protecting every party against unfair terms, whereas the black and grey lists protect consumers more in particular.

\section{En Guise de Conclusion}

Should consumer law remain in the books: should we live with it for another half century, so that in 2062 its first centenary may be celebrated? It is in general not so easy to predict the future, but in the case of law - often following changes in society by a margin of decades if not centuries - this appears to be different. Three scenario's seem to be possible: the disappearance model, the status quo model and the independence model. The disappearance model would mean that consumer protection is considered an emancipation movement. ${ }^{27}$ Once its aims have been met, the rules it has engendered can either be abolished-price control - or integrated in other legislation and enforcement machinery. Often, legislatures have considered specific rules on for instance rent control, anti-discrimination, or consumer protection to be of a temporary nature, not fit to be included in codifications such as a Civil Code, with their aere perennius character: more durable than bronze. ${ }^{28} \mathrm{~A}$ second model is to keep matters as they are: consumer protection is a little apart, but not too much. Its regulation is integrated as much as possible in the Civil Code and other major legislative instruments; its enforcement is entrusted to special authorities but the final say is to the ordinary courts. A third model seeks to bring all consumer protection measures together in one big Code de la consommation $^{29}$ or Codice del consumo. ${ }^{30}$ On earlier occasions, I have advocated, at least

\footnotetext{
${ }^{26}$ See for instance as far as Environmental law is concerned Aalders and Uylenburg (2007), and for health law Martin Buijsen, Theorie en definitie van het gezondheidsrecht, inaugural address Erasmus University Rotterdam, 2010.

${ }^{27}$ In this sense, Augenhofer (footnote supra), at p. 1078: "Dann bedeutet Zukunft vielleicht auch Abschied vom Verbraucher - aber zugleich die Verwirklichung des mit diesem Rechtsgebiet eigentlich verfolgten Ziels, nämlich die selbstbestimmte Wahrnehmung der Privatautonomie durch den Einzelnen zu gewährleisten."

${ }^{28}$ Horace, as quoted in the inaugural lecture of J.C. van Oven (Over de onvergankelijkheid van het privaatrecht, Leiden, 1956).

${ }^{29}$ See Calais-Auloy and Temple (2010), who criticize the lack of coherency in the Code, which has been aggravated by the incorporation of many new texts after its entry into force in 1992, but who on the whole consider it useful: "il facilite l'accès au droit, dans une matière qui intéresse la vie quotidienne de tous les citoyens" (p. 38).

${ }^{30}$ Available in English on the website $<$ codicedelconsumo $>$.
} 
for my own country, the second model. ${ }^{31}$ This in my view combines the best of two worlds. On the one hand, it does allow the introduction of specific rules and enforcement machineries where needed. On the other hand, it leaves unscathed the structure of private law, administrative law, and criminal law and does not deprive these from some of their most frequent themes.

Open Access This article is distributed under the terms of the Creative Commons Attribution License which permits any use, distribution, and reproduction in any medium, provided the original author(s) and the source are credited.

\section{References}

Aalders, M. V. C., \& Uylenburg, R. (Eds.). (2007). Het milieurecht als proeftuin/20 jaar Centrum voor milieurecht. Amsterdam: Centrum voor milieurecht.

Arentsen, M. J., van Rossum, W., \& Steenge, A. E. (Eds.). (2010). Governance of innovation. Firms, clusters and institutions in a changing society. Cheltenham: Elgar.

Augenhofer, S. (2010). Die Zukunft des Europäischen Verbraucherrechts und seine Bedeutung für die Weiterentwicklung des Vertrags- und Wettbewerbsrechts. In S. Grundmann, M. Kloepfer, C. G. Paulus, R. Schröder, \& G. Werle (Eds.), Festschrift 200 Jahre Juristische Fakultät der Humboldt-Universität zu Berlin. Geschichte, Gegenwart und Zukunft (pp. 1051-1054). Berlin: De Gruyter.

van Boom,W. (2009). Collective settlement of mass claims in the Netherlands. In M. Casper, A. Janssen, P. Pohlmann, \& R. Schulze (Eds.), Auf dem Weg zu einer europäischen Sammelklage? (pp. 171-192). München: Sellier

van Boom, W., \& Faure, M. (Eds.). (2007). Shifts in compensation between private and public systems. Vienna: Springer.

Brownsword, R., Micklitz, H.-W., Niglia, L., \& Weatherill, S. (Eds.). (2011). The foundations of European private law. Oxford: Hart.

Calais-Auloy, J., \& Temple, H. (2010). Droit de la consommation (8th ed., pp. 36-39). Paris: Dalloz.

Duffy, J. (2007). Inventing innovation: a case study of legal innovation. Texas Law Review, 86, 1-3.

Eidenmüller, H., Faust, F., Grigoleit, H. C., Jansen, N., Wagner, G., Zimmermann, R. (2008). The Common frame of reference for European private law_policy choices and codification problems. Oxford Journal of Legal Studies, 28, 659-708.

Ernst, W. (Ed.). (2010). The development of traffic liability. Cambridge: University Press.

Faure, M., \& van der Walt, A. (Eds.). (2010). Globalization and private law: the way forward. Cheltenham: Elgar.

Faure, M., \& Verhey, A. (Eds.). (2007). Shifts in compensation for environmental damage. Vienna: Springer. Gordley, J. (Ed.). (2010). The development of liability between neighbours. Cambridge: University Press.

Gsell, B., \& Herresthal, C. (Eds.). (2009). Vollharmonisierung im Privatrecht. Tübingen: Mohr.

Hodges, C. (2008). The reform of class and representative actions in European legal systems. A new framework for collective redress in Europe (Vol. 319, pp. 70-76). Oxford: Hart.

Hondius, E. (Ed.). (2010). The development of medical liability. Cambridge: University Press.

Jansen, N. (Ed.). (2010). The development and making of legal doctrine. Cambridge: University Press.

van Kampen, S. (2011). Het duale handhavingsstelsel van de Consumentenautoriteit: een zorgenkindje? In I. Bakker \& F. B. en Ewoud Hondius (Eds.), De toekomst van het consumentenrecht. Zestien opstellen over consumentenbescherming in de $21^{e}$ eeuw. Utrecht: Molengraaff Instituut.

Keirsbilck, B. (2011). The new European law of unfair commercial practices and competition law, PhD Leuven. Oxford: Hart.

Keirse, A. (2009). Fraternalisme en trouw aan het gegeven woord. Contracteren, 105-109.

Klap, A. (1994). Vage normen in het bestuursrecht, PhD thesis Leiden, Zwolle: Tjeenk Willink.

Klosse, S., \& Hartlief, T. (Eds.). (2007). Shifts in compensating work-related injuries and diseases. Vienna: Springer.

Loos, M. (2011). Harmonisatie van het consumentencontractenrecht. Nederlands Juristenblad, 408-414.

\footnotetext{
${ }^{31}$ See my paper "Consumer law and private law-the case for integration," in: Heusel (Ed), Neues Europäisches Vertragsrecht und Verbraucherschutz, Trier: ERA, 1999, p. 19.
} 
Lorandi, F., \& Staehelin, D. (Eds.). (2011). Innovatives Recht. Festschrift für Ivo Schwander. Zürich: Dike. Lurger, B. (2010). The 'social' side of contract law and the new principle of regard and fairness. In A. Hartkamp, M. Hesselink, E. Hondius, C. Mak, \& E. du Perron (Eds.), Towards a European Civil Code (4th ed., pp. 353-386). Nijmegen: Ars Aequi.

Luth, H. (2010). Behavioural economics in consumer policy: the economic analysis of standard terms in consumer contracts revisited, $\mathrm{PhD}$ thesis Rotterdam. Antwerpen: Intersentia.

Martín-Casals, M. (Ed.). (2010). The development of liability in relation to technological change. Cambridge: University Press.

Möslein, F. (2010). Legal innovation in European contract law: within and beyond the (draft) common frame of reference. In H.-W. Micklitz \& F. Cafaggi (Eds.), European private law after the Common Frame of Reference (pp. 173-200). Cheltenham: Edward Elgar.

Muller, S., Zouridis, Z., Frishman, M., \& Kistemaker, K. (Eds.). (2011). The law of the future and the future of law. Oslo: Torkel Opsahl.

van Nimwegen, E. S. (2010). Handhaving door de Consumentenautoriteit: Een goed samenspel met het Burgerlijk Wetboek en Europese regelgeving? Contracteren, 54-59.

Reymann, C. (2009). Das Sonderprivatrecht der Handels-und Verbraucherverträge, Habilitationsschrift Saarbrücken. Tübingen: Mohr.

Rott, P., \& Terryn, E. (2010). Right of withdrawal and standard terms. In H.-W. Micklitz, J. Stuyck, \& E. Terryn (Eds.), Cases, materials and text on consumer law (pp. 239-302). Oxford: Hart.

Schulte-Nölke, H., Twigg-Flesner, C., \& Ebers, M. (Eds.). (2008). EC Consumer Law Compendium. The Consumer Acquis and its transposition in the Member States. München: Sellier.

Stürner, M. (Ed.). (2010). Vollharmonisierung im Europäischen Verbraucherrecht. München: Sellier.

Twigg-Flesner, C. (2010). Time to do the job properly - the case for a new approach to EU consumer legislation. Journal of Consumer Policy, 33, 355-375.

Vranken, J. B. M. (1989). Mededelings-, informatie- en onderzoeksplichten in het verbintenissenrecht. Zwolle: Tjeenk Willink.

Whittaker, S. (Ed.). (2010). The development of product liability. Cambridge: University Press. 